\title{
Photovoltaics for Rural Development in Latin America: A Quarter Century of Lessons Learned
}

\author{
Alma Cota ${ }^{1}$ and Robert Foster ${ }^{2}$ \\ ${ }^{1}$ Universidad Autónoma de Ciudad Juárez \\ ${ }^{2}$ New Mexico State University \\ ${ }^{1}$ México \\ 2United States of America
}

\section{Introduction}

Over the past quarter century, Latin America has widely adopted photovoltaic (PV) technologies for social and economic development. Latin America is the world's birthplace for small rural solar electric systems used for residential power, refrigeration, distance education and hybrid systems. The use of PV systems has increased dramatically from an initial concept pioneered by a few visionaries to many thriving businesses throughout the rural regions today.

$\mathrm{PV}$ is a viable alternative to conventional large-scale rural grid systems. With the advent of $\mathrm{PV}$ as a dependable technology alternative allowing local private enterprise, and made available to the general public, PV systems have become attractive all over Latin America with hundreds of thousands of rural households electrified via solar energy.

During the early 1980s, solar energy pioneers began to disseminate PV technologies in rural Latin America as a solution for providing basic electricity services for non-electrified populations. Some of the first pilot projects in Latin America were undertaken by NGOs, such as Enersol Associates in the Dominican Republic, beginning in 1984. In the late eighties, small solar companies began to form gradually throughout Latin America; the key module manufacturers such as Solarex and Arco sought out distributors for off-grid rural markets.

By the mid-1990s, these activities were followed by large-scale solar electrification activities sponsored by government agencies in Mexico, Brazil, Colombia, Bolivia and Peru. Many of these early governments efforts for large-scale PV electrification faced sustainability issues; planners attempted to force "free" solar electrification projects onto unknowledgeable rural users.

In Mexico, there were large-scale government PV rural electrification projects undertaken under PRONASOL (a Mexican program to better people lifestyle) in the early to mid-1990s with over 40,000 PV systems installed, especially in southern Mexico. In the State of Chiapas more than 12,000 systems were installed. The government also dabbled in village scale PV and wind electrification. Unfortunately, over two thirds of these systems ceased functioning in only a couple of years. The era of large PV electrification projects in Mexico came to a temporary halt in the late 1990s, in large part due to the poor performance and image of these original substandard PV systems. Typical problems on PV systems installations were not related to the PV modules, but rather due to poor quality installations and problems 
with balance of systems due to inappropriate use of battery technologies and substandard charge controllers.

In response to early system failures, implementing agencies gradually began to adopt more rigid technical specifications that observed international standards that improved the quality and reliability of PV systems. Some examples include the World Bank/Nicaraguan Comission of Energy (Comisión Nacional de Energía de Nicaragua) Program for the electrification of 6,000 homes in the rural regions of Nicaragua, and the World Bank in Bolivia for the PV electrification of 10,000 homes. However, there are still issues of enforcement of standards where they do exist.

To promote a reliable introduction of PV technologies in Latin America, it is of great importance to bring early capacity building that tends to focus on PV specific applications to create a knowledgeable engineering base in country. Sandia National Labs (SNL) and New Mexico State University (NMSU) held many of the early capacity building activities, including the first PV and wind workshop in Central America, in Guatemala in 1992 under the USAID/DOE/US Export Council for Renewable Energy - Latin American Renewable Energy Cooperation Program. Over the next 15 years, hundreds of workshops were held by US government, World Bank, etc. training thousands of engineers and technicians on PV applications such as household lighting, water pumping, refrigeration, communications, clinics, and schools in Brazil, Chile, Ecuador, Honduras, Jamaica, Guatemala, Mexico, Panama, Peru, and the Dominican Republic.

Many of these trained engineers and planners were later responsible for implementing the first PV electrification projects, such as the 1993 EEGSA project in the community of San Buenaventura, Guatemala for 68 homes using $50 \mathrm{~W}$ systems. Likewise, the founding of Guatemala's Fundación Solar in 1993 furthered progress by installing over 3,000 PV household-electrification systems, mostly in the Quiché and Verapaz regions.

The Mexico Renewable Energy Program (MREP) was designed to expand the use of renewable energy technologies for Mexico's rural development (Foster et al., 2009, Cota, 2004). MREP was launched in 1992 by the US Department of Energy (DOE) and the US Agency for the International Development (USAID) and was managed by SNL (Richards et al., 1999). Various Mexican program partners have collaborated with MREP, including the Fideicomiso de Riesgo Compartido (FIRCO) for the deployment of PV systems for agriculture. The key application supported by MREP between 1994 and 2000 was PV water pumping systems for livestock and community water supply (Cota et al., 2004), although additional projects included PV lighting (Foster et al., 2004), communication, education (Foster et al., 2003, Ley et al., 2006), ice-making (Foster et al., 2001, Foster 2000, Hoffstatter and Schiff, 2000), and refrigeration systems (Estrada et al., 2003), as well as a few windenergy projects (Romero Paredes et al., 2003, Foster et al., 1999, Ley and Stoltenberg, 2002). The project continued its work until 2005 and directly installed over 500 solar and wind systems, and spun off with the application of an additional 3,000+ more systems across Mexico. However, the main impact was the capacity building of the Mexican solar energy industry and increasing the quality of installed systems.

\section{PV home systems in Mexico}

Rural Latin households pay anywhere from US\$5-25/month for dry cell batteries and kerosene lighting, the main energy source PV competes against. Rural users mostly use electricity for lighting and entertainment with radio and TV. In 1998, a market study was 
undertaken in rural Chihuahua by NMSU under the MREP to determine what the average consumer willingness to pay (WTP) was for PV lighting systems (Foster et al., 1998a). Chihuahuans were found to be favorably disposed to the concept of solar PV systems as an alternative source of energy for their homes. At the time, non-electrified households in Chihuahua were already spending about US\$25 per month for gas powered lights and small dry cell batteries for radios, and were willing to pay similar amounts of money to displace those services through PV.

In 1999, one hundred forty five innovative high quality PV home lighting systems were installed in the State of Chihuahua as part of the MREP. A total of 120 systems were installed in the Municipality of Moris, as well as an additional 15 systems in the municipality of Nonoava and 10 systems in Bachíniva, totaling $7.3 \mathrm{~kW}$ and benefiting about 800 people.

The municipality of Moris is located about $250 \mathrm{~km}$ west of Chihuahua City, from which it takes about 8 hours to arrive in vehicle. The terrain consists of steep mountains and 1,000 $\mathrm{m}$ deep canyons in the midst of pine forests. The arid climate is hot in the summer $\left(\sim 40^{\circ} \mathrm{C}\right)$ and cold in the winter $\left(<0^{\circ} \mathrm{C}\right)$. The steep topography makes electric grid access difficult and indeed there is no interconnection with the national electric grid, nor are there paved roads. Over 3/4 of Moris residents do not have access to electricity, and the few that do are mostly on diesel powered mini-grids.
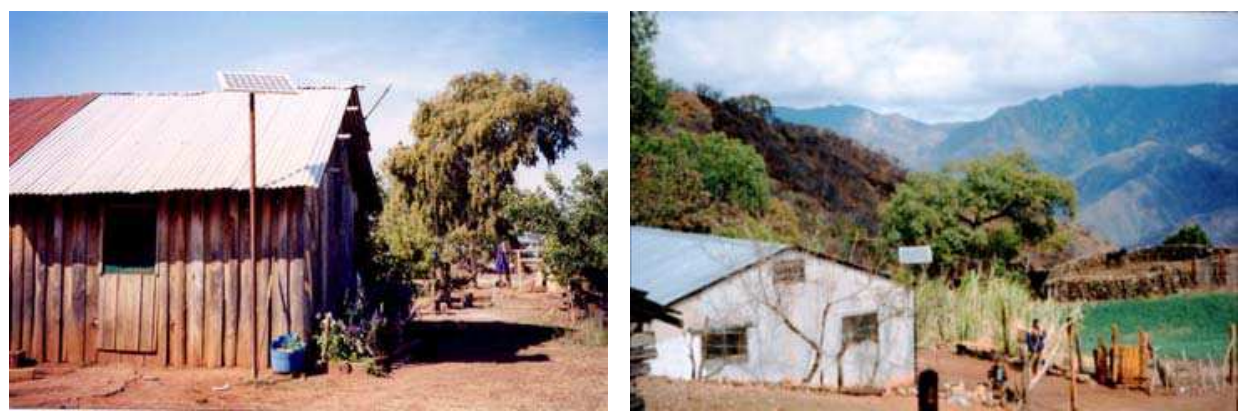

Fig. 1. 50 Wp PV lighting system installed in Talayotes, Moris County, Chihuahua.

\subsection{Financing program for household lighting}

The State of Chihuahua, working with MREP, designed the first Mexico's first ever pilot renewable energy financing program. The objective was to promote the use of renewable energy technologies in rural areas that lie outside the national electric grid. The financing activities were conducted by the State Trust Fund for Productive Activities in Chihuahua (FIDEAPECH - Fideicomiso Estatal para el Fomento de las Actividades Productivas en el Estado de Chihuahua) (Ojinaga et al., 2000). This state trust fund provides direct loans and guarantees, primarily based on direct lending (e.g., to farmers for tractors). For this project, FIDEAPECH used US\$99,000 of MREP seed funding from USAID to support renewable energy projects. FIDEAPECH implemented the revolving fund in which the municipality paid up front $33 \%$ of the total cost of PV home lighting systems, end users provided a down payment of $33 \%$, and the remaining $34 \%$ was financed for one year by FIDEAPECH. The municipal government provided the loan guarantee and eventual repayment to FIDEAPECH. The total installed cost of each quality code compliant PV home lighting 
system was about US $\$ 1,200$. The FIDEAPECH financing program went on to roll over its seed capital four times.

Other financing and leasing programs have been initiated in Nicaragua, Bolivia, Dominican Republic, Honduras, etc. by such organizations as the World Bank and companies like Soluz. These programs have had mixed results and generally PV systems leasing has not been successful in part due to rural seasonal incomes. PV financing programs can be set up in rural Latin America to compete with conventional technologies so long as financing terms are compatible with current rural user expenses and seasonal incomes.

\subsection{System design}

NMSU worked closely with the Chihuahua Renewable Energy Working Group (GTER) to implement a quality PV lighting system project. NMSU assisted GTER with the development of a technical specification for the PV lighting systems that would comply with the Mexican electrical code (NOM-Norma Oficial Mexicana) (Wiles, 1996). The NOM essentially mirrors the US National Electrical Code (NEC); Article 690 of both directly applies to PV installations. The NOM had not previously been applied in Mexico for the thousands of PV lighting systems installed. Besides meeting legal guidelines, NOM compliance can extend system reliability, lifetime, and safety.

The Solisto PV systems were designed by Sunwize Technologies to meet NMSU specifications based on the Mexican electric code (Wiles, 1996). This is a prepackaged control unit engineered for small-scale rural electrification and long life. The Moris PV systems consist of one $50 \mathrm{~W}$ Siemens SR50 module, which was the first deployment of these modules that were specifically developed for the rural lighting market. The PV modules are mounted on top of a 4-meter galvanized steel pole capable of withstanding high winds. The module charges a nominal $12 \mathrm{~V}$ sealed gel VRLA battery (Concorde Sun-Xtender, $105 \mathrm{Ah}$ at C/20 rate for $25^{\circ} \mathrm{C}$ ). These are sealed, absorbed glass mat (AGM) and never require watering. The immobilized electrolyte wicks around in the absorbed glass mat, which helps the hydrogen and oxygen that form when the battery is charged to recombine within the sealed cells. The thick calcium plates are compressed within a micro-fibrous silica glass mat envelope which provides good electrolyte absorption and retention with greater contact surface to plates than gelled batteries. The Concorde batteries are in compliance with UL924 and UL1989 standards as a recognized system component. These batteries meet US Navy specification MIL-B-8565J for limited hydrogen production below 3.5\% during overcharging (less than $1 \%$ in Sun-Xtender's case), which means they are safe for use in living spaces. All batteries were installed inside a spill proof heavy plastic battery case strapped shut and childrenproof. Control is maintained through the Solisto power center via a UL listed Stecca charge controller with a 10 A fuse. The system has a dc disconnect and 6 other dc fuses protecting different circuits. The controller uses fuzzy logic to monitor battery charging to avoid under or overcharging the battery and is equipped with an LED lighted display to indicate state of charge. The Solisto power center is still available on the commercial market; Chihuahua marked the first use of these power centers in the world.

The PV system powers three compact fluorescent lamps with electronic ballasts (20 W each). It also has a SOLSUM dc-dc voltage converter (3, 4.5, 6, 7.5, $9 \mathrm{~V}$ options) and plug to allow for use of different types of appliances, such as radio and TV. For an extra of US\$200, endusers could also elect to install a Tumbler Technologies Genius 200 W inverter, although few chose to do so. Five users immediately decided to install the satellite DirectTV service upon 
installation, which comfortably allowed them about $3 \mathrm{~h}$ of color TV viewing with this service in the evenings. The design of the Solisto SHS assumed that a household using the full set of 3 fluorescent lamps ( $20 \mathrm{~W}$ each) for an average $2 \mathrm{~h}$ a day would consume about $120 \mathrm{Wh} /$ day on average.

Given that Chihuahua averages about 6 sun-hours per day annually, and assuming an overall PV system efficiency of $60 \%$ for this fairly well designed system (i.e., including battery efficiency losses, module temperature derate, line losses, etc.), the user could expect on average to have about $180 \mathrm{Wh} / \mathrm{d}$ of available power. There are seasonal variations and double or more power could be extracted from the battery on any single day, but could not be sustained long-term. As is typical for solar energy users, they quickly learned to live within finite energy system bounds and learned to ration energy use during extended cloudy periods, which are fortunately relatively rare in Chihuahua. As part of the project specifications, the installer was required to provide end-user training on how to properly maintain and operate the PV system, as well as a simple user instruction booklet.

\subsection{System evaluation}

From 1999 until 2008, the performance of a Solisto PV lighting system was continuously monitored at NMSU's Southwest Region Solar Experiment Station in Las Cruces, New Mexico, simulating usage of about $171 \mathrm{Wh} /$ day. Climate and irradiance conditions in Las Cruces are very similar to those found in Moris, Chihuahua (less than $500 \mathrm{~km}$ distant), and the system is housed in an unconditioned house that performs similarly to unconditioned homes in Moris (i.e., no HVAC system). The long-term monitoring provides a reasonable base case with which to compare fielded systems.

Measured parameters include solar irradiance (at $32^{\circ}$ tilt), ambient temperature, battery temperature, PV current, battery voltage, and load current. Each parameter is sampled every ten seconds and averaged each hour and recorded. Lights are operated automatically by the data acquisition system with a timing circuit that turns on all 3 lights for two hours at 7:00 a.m., and then again for another two hours at 7:00 p.m., for a total daily usage of four hours for three lights. Note that several different types of fluorescent lights are tested, including the original Moris lights, for a total nameplate rating of $43 \mathrm{~W}$. In Moris loads will vary, but the NMSU monitored system base load provides a meaningful average that utilizes the average daily PV power production. The charge controller has successfully protected the battery from severe abuse from overcharging and deep discharging during prolonged cloudy periods. The nominally regulated voltage on the battery averaged 12.9 Vdc each day, with the lowest battery voltages observed as $11.9 \mathrm{Vdc}$ after cloudy periods. Discharge to charge ratio for the battery indicated a battery roundtrip efficiency of about $83 \%$, with an average daily depth-of-discharge (DOD) of about $13.5 \%$.

\subsection{Field surveys}

The intent of the Chihuahua pilot project was to demonstrate that simple PV lighting systems could be designed to provide reliable, essentially maintenance free electrical service for many years with full cost recovery. After nearly five years of operation, random field surveys were conducted of 35 homes in Moris and found that over $90 \%$ of the Solisto PV home lighting systems have performed exceptionally well without any significant problems (Foster et al., 2004).

Performance was assessed through electrical measurements, visual inspection, and an enduser survey to determine user satisfaction. The 2003 survey results showed that over $80 \%$ of 
the installed systems were operating correctly and as designed, $11 \%$ were in fair condition (e.g., most commonly one of three lamps was no longer working), $6 \%$ were non-operational, and $3 \%$ of systems had been dismantled (e.g., user moved). The high percentage of working PV lighting systems after nearly five years demonstrates a new degree of reliability for PV home lighting systems rarely seen in Mexico before.

In the household survey, $94 \%$ of users expressed complete satisfaction with their PV lighting systems, $86 \%$ thought that PV was better than their previous gas lighting source, and $62 \%$ believed that the PV systems were reasonably priced for the service provided. New and expanded evening activities were also reported such as sewing, TV, reading, and studying. After five years, the PV systems have saved about US\$300 in lieu of previous gas and dry cell battery options, while providing superior light and entertainment capabilities. The average rural family income in Moris is about US\$3,000 per year (Ojinaga et al., 2000), which represents a monetary savings for these rural families of about $10 \%$ per year. There will be additional future replacement expenses as the batteries and lamps come to the end of their useful lives; however, a number of system components like the PV modules are already an investment that will continue to pay off for years to come.

Among the few component failures experienced within the first four years of operation were individual lamps and ballasts in 9 systems. Some of the failed lamps had been since replaced by the users with conventional incandescent bulbs. Blown fuses were found in 6 systems, but the systems were still functional. The few blown fuses were due to users placing large loads above the fuse rating $(2.5,5,7$, and $10 \mathrm{~A}$ fuses used) along with users tampering with the system wiring in an attempt to bypass blown fuses rather than replace them. Batteries had been dismantled or swapped out in 4 cases (they had not actually failed), and charge controllers bypassed in 2 systems.

The sealed battery lifetimes have been very good and much better than most similar PV lighting systems used in Mexico, where batteries rarely last more than two years. Of the original Moris sealed maintenance-free 105 Ah batteries installed, only four had been replaced (they had been sold for cash) and typically replaced with a larger battery bank consisting of truck batteries ranging from 65 to $100 \mathrm{Ah}$. The four original sealed batteries dismantled or sold apparently had not actually failed; the users simply wanted a larger battery bank. In two cases, the owners had disconnected the charge controllers to override the low voltage disconnect. These users did mention that the shallow cycle replacement car/truck batteries did not last as long as the original deep-cycle batteries, but they had not attempted to make the effort to obtain more expensive deep-cycle batteries to expand their battery bank. PV modules proved to be one of the most reliable components, all modules were functional and no module problems had been reported.

The average daily electricity consumption was estimated by asking users their perceived time schedule for hourly use of appliances on an average day. Users were asked in the month of May, thus usage was more reflective of that month than winter months. This survey reflects their opinion and is not measured load data. The mean value was found to be $248 \mathrm{Wh} /$ day ( $20 \mathrm{Ah} /$ day). This implies a daily cycling of about $20 \%$ DOD of the battery at $25^{\circ} \mathrm{C}$, which implies these batteries should last about 3,000 cycles ( $~ 8$ years). Given this level of usage, the batteries in Moris eventually lasted from 7 to 9 years before the first battery replacement was needed. With today's LED technologies, even longer lifetime are possible. There was an increase in the electricity consumed in some households from the purchase of additional appliances such as radios and TV, but the PV systems handled the increased loads. 


$\begin{array}{llll} & \text { Daily Average } & \text { Max } & \text { Min } \\ \text { Insolation } & 6.1 \mathrm{kWh} / \mathrm{m}^{2} & & \\ \text { PV Power } & 32.1 \mathrm{~W} & & \\ \text { PV Current } & 2.1 \mathrm{~A} & & \\ \text { PV Energy } & 258 \mathrm{Wh} / \mathrm{d} & & \\ \text { Battery Charge } & 205 \mathrm{Wh} / \mathrm{d} & & \\ \text { Battery Discharge } & 171 \mathrm{Wh} / \mathrm{d} & & \\ \text { Net Energy } & 34 \mathrm{Wh} / \mathrm{d} & & \\ \text { Avg. DOD } & 13.5 \% & 14.0 \mathrm{~V} & 11.9 \mathrm{~V} \\ \text { Avg. Voltage } & 12.9 \mathrm{~V} & -3.4 \mathrm{~A} \\ \text { Avg. Current } & 1.2 \mathrm{~A} & 35.1^{\circ} \mathrm{C} & 28.2^{\circ} \mathrm{C} \\ \text { Temperature } & 30.5^{\circ} \mathrm{C} & & \\ \text { Load Actual Power } & 39.4 \mathrm{~W} & & \\ \text { Load Avg. Current } & 3.1 \mathrm{~A} & & \\ \text { Load Avg. Voltage } & 12.4 \mathrm{~V} & & \\ \text { Load } & 171 \mathrm{Wh} / \mathrm{d} & \end{array}$

Table 1. Summary of the performance of the sunwize solisto PV system.

\section{PV water pumping}

PV water pumping is a small-scale application of great importance all over the world, has particular impact in rural communities where electrical network has not been extended. These systems are characterized by high reliability, long life and minimum maintenance, which translate to lower long-term cost when compared with other alternatives. Also does not require an operator, and its operation does not pollute the environment and produces no noise. Another advantage is that the systems are modular, so it can be adapted to meet the specific needs of the user at any time.

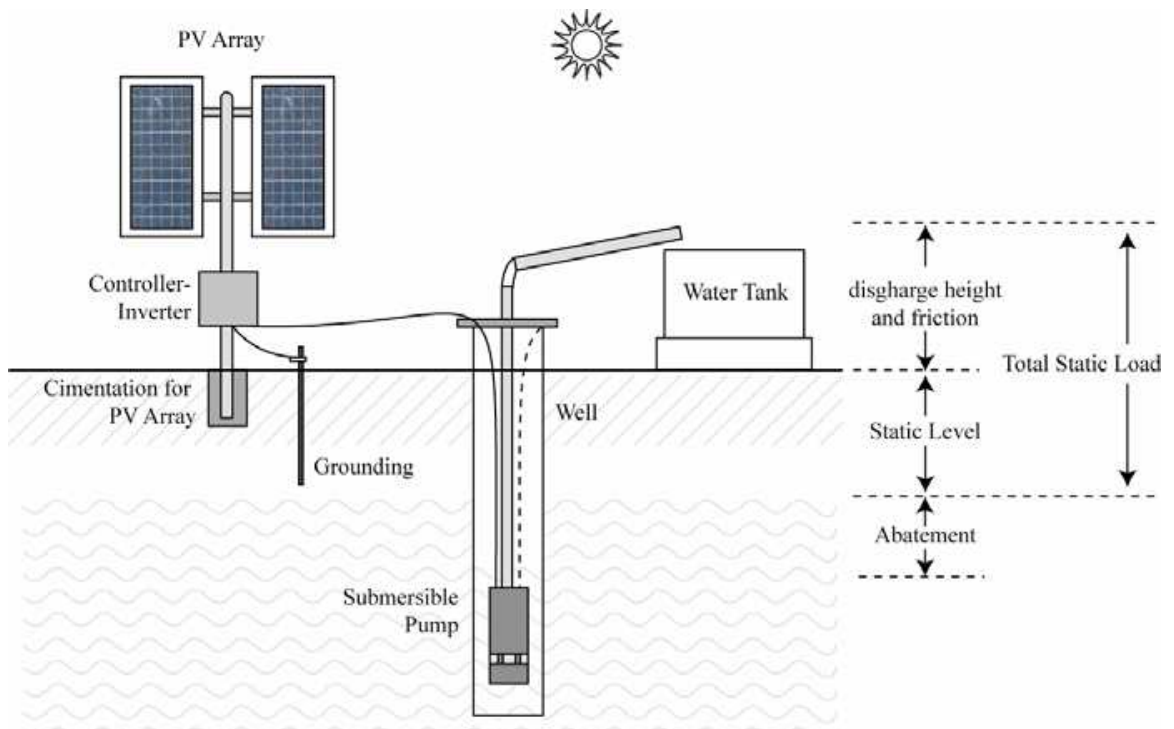

Fig. 2. Diagram of a PV system for water pumping. 


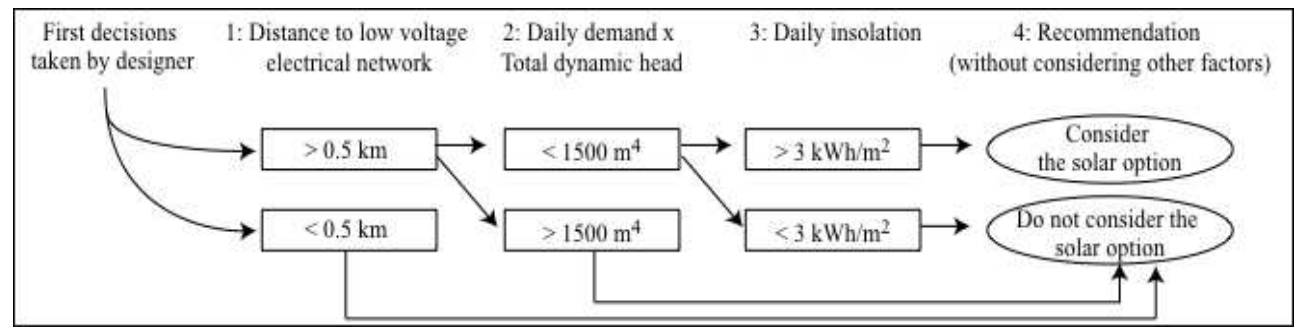

Fig. 3. Diagram for making a decision to use a PV system for pumping water.

PV systems have proven to be an excellent option in meeting water pumping where electrical grid service does not exist. Between 1994 and 2005, over 1,700 PV water pumping systems were installed throughout Mexico, initially as part of a MREP, and later with GEF/World Bank renewables for agriculture program. PV water pumping was largely unknown in Mexico prior to 1994, and MREP paved the way for widespread adoption in Mexico, which leads Latin America in this application.

Given that PV water pumping was largely unknown in Mexico and had a relatively poor reputation prior to 1994, US\$2.2 million of USAID pilot hardware funds were used to buy down the PV system risk from the users perspective and were leveraged by additional user cost-share buy-in ( US\$1.8 million) and additional Mexican agency implementation and administrative support ( $\sim$ US $\$ 0.5$ million). DOE funds supported MREP technical assistance to Mexican partners from SNL, NMSU, Ecoturismo y Nuevas Tecnologías, Winrock International, and Enersol Associates. MREP worked with established Mexican agencies for project implementation, in particular FIRCO and the State of Chihuahua (Richards et al., 1999).

Between 1994 and 2000, 206 PV water pumping pilot systems were installed in Mexico as part of the MREP. Most MREP PV water pumping systems were installed in the northern deserts of Mexico in rural areas that suffer from severe water shortages. Underground water is indispensable in these areas to meet daily water needs for domestic, crop, and livestock uses. Traditional water pumping systems powered by diesel or gasoline engines have been used for decades. However, the cost and transportation of fuel, and also engine maintenance, make conventional water pumping technologies expensive for people living in rural areas. One solution to reduce total system and operational cost of conventional water pumping systems is to replace them with PV systems. These may offer a less expensive lifecycle-cost option in many cases. Line extension of the utility grid is prohibitively costly at over US\$9,000/ km, depending on terrain. Distance to the grid ranges from a few to dozens of kilometers in many cases.

Typical installed system configurations included a PV array ( $500 \mathrm{Wp}$ on average), pump, controller, inverter (only for ac powered pumps), and overcurrent protection devices, generally installed in compliance with the Mexican National Electric Code (NOM-Norma Oficial Mexicana), which parallels the US National Electrical Code (NEC).

Table 2 presents a summary of the 206 PV water pumping pilot systems that were installed under MREP in Mexico. A total of $101 \mathrm{~kW}$ of PV were installed benefiting 9,389 people. For the first three years, MREP was cost-sharing about $80 \%$ of total system costs. After 1996, Mexican counterparts were convinced of the effectiveness of PV technology for water 
pumping; thus, their willingness to pay gradually increased from about $20 \%$ up to $85 \%$, dropping MREP cost-sharing to only $15 \%$ by 2000. After 2000, FIRCO has installed over 600 additional PV water pumping systems to date under a World Bank/GEF Renewables for Agriculture Program in Mexico.

\begin{tabular}{|rrrrrrrrr} 
& 1994 & 1995 & 1996 & 1997 & 1998 & 1999 & 2000 & $1994-2000$ \\
\hline Total kW installed & 1.8 & 2.5 & 16.9 & 34.4 & 26.4 & 16.6 & 2.6 & 101.1 \\
Number of Systems & 6 & 5 & 24 & 66 & 59 & 41 & 5 & 206 \\
Direct Beneficiaries & 482 & 242 & 1,511 & 2,705 & 3,009 & 1,400 & 37 & 9,389 \\
Avg. System Size, Wp & 300 & 507 & 704 & 521 & 446 & 404 & 514 & 491 \\
Avg. \$/Watt & $\$ 22.01$ & $\$ 22.87$ & $\$ 18.96$ & $\$ 19.06$ & $\$ 19.81$ & $\$ 22.49$ & $\$ 14.77$ & $\$ 19.98$ \\
MREP Cost-Share \% & 78.10 & 86.50 & 82.90 & 63.10 & 41.90 & 36.40 & 15.00 & 57.60 \\
Mexican Cost-Share \% & 21.90 & 13.50 & 17.10 & 36.90 & 58.10 & 63.60 & 85.00 & 42.50
\end{tabular}

Table 2. Summary of the 206 PV water pumping pilot systems installed under MREP.

After ten years of MREP PV system implementation, FIRCO, NMSU, and SNL conducted a review in 2004 on over $1 / 5$ of the first installed PV pumping systems. The objective of the review was to determine technical status, reliability, and user acceptance of systems after several years of owning and operating such systems. After performing the technical evaluations, it was found that over $3 / 5$ of the surveyed systems were operating appropriately after as much as 10 years of operation. A total of $85 \%$ of users thought that PV systems had excellent to good reliability.
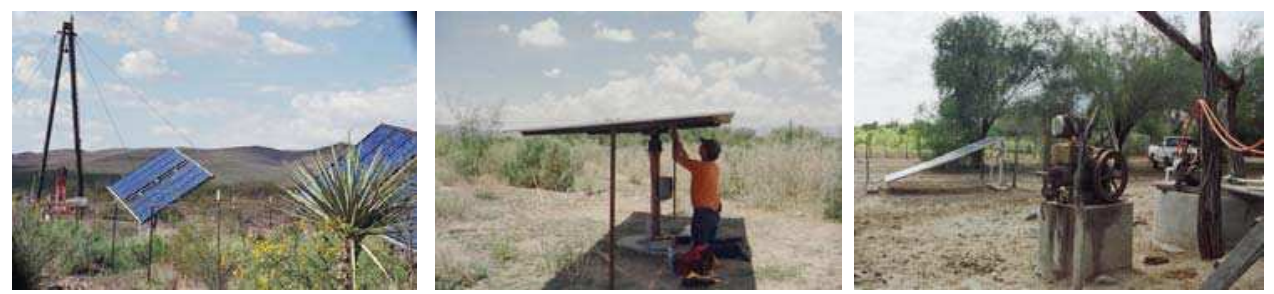

Fig. 4. PV water pumping systems in Chihuahua and Baja California Sur, and FIRCO engineer conducting performance evaluation.

\subsection{Review of PV water pumping systems}

Field surveys began in July of 2003 and continued until March 2004. During these visits, either the owner or the responsible person operating the PV water pumping system was surveyed. A total of 44 questions were included and classified into eight sections, which were: (1) general demographic information and system specifications; (2) information of traditional pumping systems used prior to PV system installation (if any); (3) user perception of vendor and installers; (4) productive and commercial impacts as a result of the use of PV pumping systems; (5) environmental impacts as a result of the use of PV pumping systems (if any); (6) replication of additional systems; (7) user lessons learned, and; (8) other renewable energy applications. 
The PV water pumping systems were visually and electrically inspected for electrical performance and pumping productivity. Electrical measurements on the PV array and the controller/inverter were made at the same time to determine water volumetric rate and solar radiation. Wiring, connectors, insulation, junction boxes, breakers, and water pipe were also inspected. Technical field inspections were carried out by engineers from FIRCO, NMSU, and EcoTursimo y Nuevas Tecnologías.

Before installing PV systems, $72 \%$ of the visited ranches had conventional pumping systems using gasoline, diesel, car engines, and one used an animal traction system. The typical consumption of gasoline for pumping water ranged from 5 to 10 liters per day for the states of Baja California Sur, Chihuahua, and Sonora. In the state of Quintana Roo, the consumption ranged from less than one liter per day up to 2.5 liters. Northern Mexico is an arid and hot region; livestock and crop production requires more water. Gasoline systems also required about 3 liters of lubricating oil per month. According to user's responses, a conventional gasoline or diesel system only lasts from 4 to 5 years. Solar pumps already exceeded this lifetime in many cases. Once the fossil fuel powered systems started to fail, they had to be repaired 2 or 3 times per year. People who were satisfied with the operation and productivity of PV water pumping systems mentioned that PV systems saved them

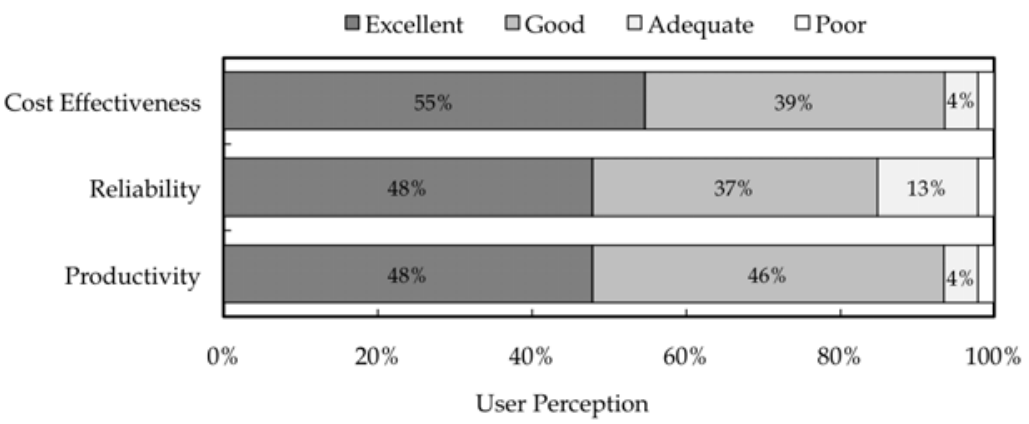

Fig. 5. User perception about cost effectiveness, reliability, and productivity of PV water pumping systems.

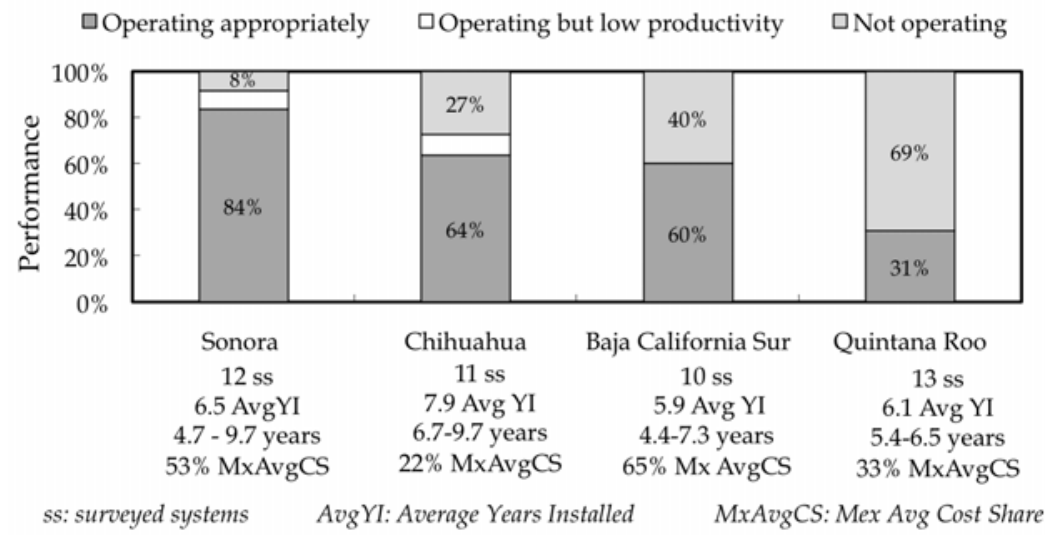

Fig. 6. Performance of surveyed systems by state. 
money and time because there is no need to buy and transport fuel, less maintenance is required, and no time is invested in operating the systems on-site as was required before. The survey results found that over 4/5 of the rural Mexican users were satisfied with the reliability and performance of their PV water pumping systems.

The majority of surveyed users in Baja California Sur, Chihuahua and Sonora responded that the work done by vendors and installers ranged from good to excellent regarding installation, training, post-sales service, and the operation and maintenance manual. On the contrary, in the state of Quintana Roo, these answers ranged from bad to adequate on vendor performance (with only two exceptions).

Due to a severe decade long drought in Northern Mexico, the desert ranches in Baja California Sur, Chihuahua and Sonora identify water as a larger issue than in tropical Quintana Roo. Regarding the productive uses of the water, from the 46 surveys, it was found that $100 \%$ used the water for livestock watering, $13 \%$ also used it for irrigation and $19 \%$ for domestic uses.

Figure 7 presents the average cost in dollars per watt of the PV water pumping pilot systems by state and installation year of MREP systems. The continuous line corresponds to the average cost for the installed systems in the State of Chihuahua. During the introduction of PV technology for water pumping, the cost was 22 and 25 dollars per installed watt in 1994 and 1995, respectively. After 1995, a decrease in cost reflecting PV market maturity was observed. By the end of 1999 , the average cost was US\$12/Wp. Over 40 systems were installed in Chihuahua. Similar results were also seen in Baja California Sur with 40 installations. In other states, the program implemented only a few projects and the PV market had not sufficiently matured and there was less vendor competition. MREP experience shows that key factors for achieving a mature market include training, program size, multiple vendors, quality workmanship, code compliance, and technologies deployed. A total of 46 of the original 206 installed PV systems (22\%) were surveyed to determine reliability and user acceptance of PV technology after owning and operating them for as much as 10 years. The survey was conducted in the states of Baja California Sur, Chihuahua, Quintana Roo, and Sonora.

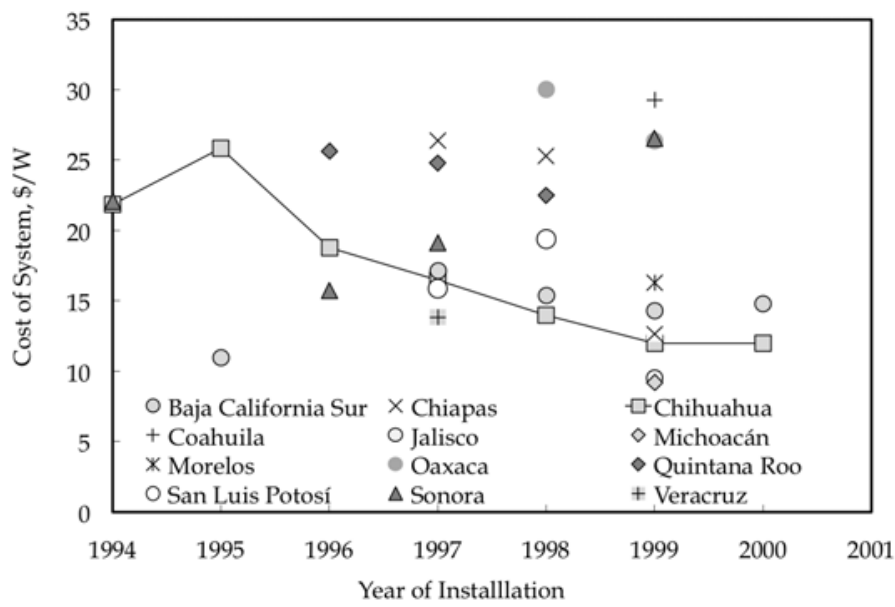

Fig. 7. Average cost of PV water systems by year and by state. 
A representative example of successful PV water pumping pilot systems is at Rancho El Jeromín in Chihuahua. The system at Rancho El Jeromín was installed in 1995 utilizing an ASE Americas $848 \mathrm{Wp}$ array to pump $12.5 \mathrm{~m}^{3}$ /day of water daily via a Grundfos pump operating at $40 \mathrm{~m}$ total head. The system has not had a single component replaced and has pumped water daily as designed for the past eight years. Full PV system payback was realized in only 2.5 years. Figure 8 presents the life cycle cost analysis for the PV system installed at Rancho Jeromín compared to the conventional diesel system previously used. Since the solar system installation, the owner has saved over US $\$ 15,000$ in fuel and maintenance, and the PV system should still provide many years of service to come. This was based on initial fuel costs of the mid-1990's of US $\$ 1.00$ per gallon. Payback would decrease proportionately as fuel prices increase (e.g., at US\$2.00 per gallon, payback is half the time.)

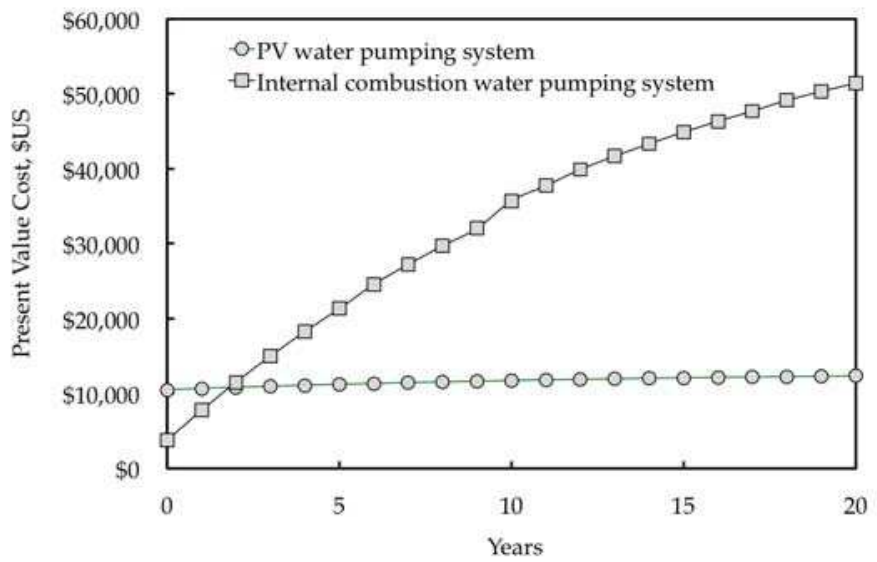

Fig. 8. PV system payback realized in 2.5 years for the Rancho El Jeromín solar vs diesel powered pump. Since system installation in 1997, the rancher has saved over US\$30,000 in fuel costs.

The average installed time for all the systems surveyed was 6.5 years. The oldest systems were installed ten years before the review and included the very first system installation in Estación Torres, Sonora utilizing a Grundfos SP3A-10 solar pumping system installed by Applied Power. This system has been operating daily since 1994 with no parts replaced or maintenance of any kind.

\section{PV ice-making and refrigeration}

In the middle of the Chihuahuan desert lies the Luis Leon Reservoir formed from the waters of the Río Conchos as seen in Figure 9. For over a quarter century, fishermen from the nearby community of Chorreras have fished this man-made lake for bass, catfish, tilapia, sunfish, and carp. Today, there are about 70 fishermen who make a reasonable living from the lake. The community is not serviced by the conventional electric grid, and it is nearly a four-hour drive from the lake to Chihuahua City to get the fish to market. Thus, the fishermen have had to rely on Chihuahuan wholesale merchants to come and purchase fish 
from them. The fishermen of Chorreras sometimes have lost fish to spoilage due to lack of ice. The fishermen also end up paying relatively high rates for the trucked-in block ice from Chihuahua when it does show up. The fishing cooperative annually harvests about 80,000 $\mathrm{kg}$ of fish. However, with no local ice source, they have had to put off fishing or take their chances that ice will arrive on time. The lack of ice also limited their ability to independently sell their fish, particularly during the high demand season of Lent in the spring.

Recognizing this problem, the State of Chihuahua and SNL joined forces to install a renewable energy powered ice-making system. The goal was to install an on-site ice-maker that could adequately meet ice needs. In response, NMSU set up a solar and wind resource monitoring system in 1995 to verify the renewable resources. While the initial concept was to install a wind-powered ice-making system, the wind resource was deemed inadequate with an annual average windspeed measured of only $3.5 \mathrm{~m} / \mathrm{s}$ (SWTDI, 1999). Thus, the concept for powering the ice-maker from PV came to the forefront with an average annual solar resource of about $6 \mathrm{kWh} / \mathrm{m}^{2} / \mathrm{d}$.
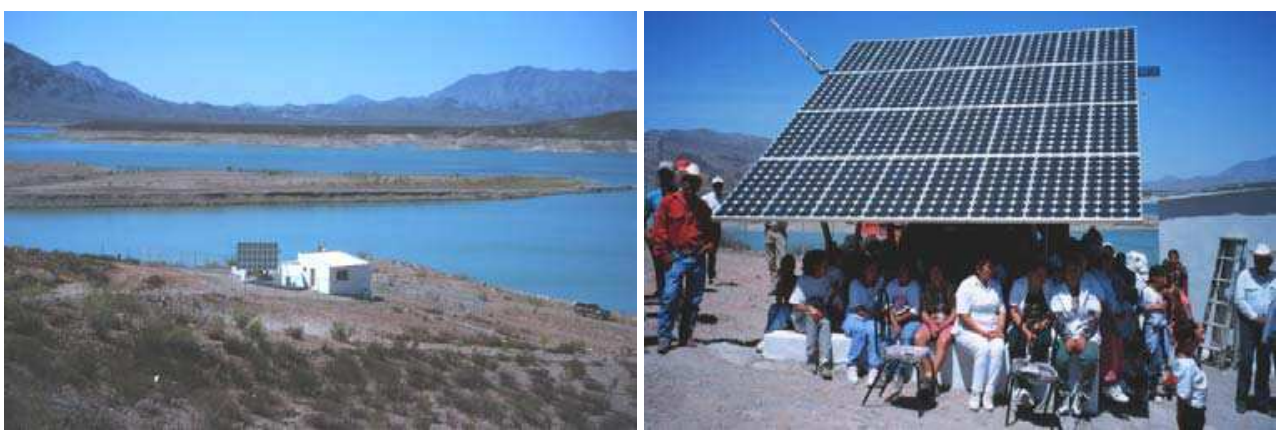

Fig. 9. World's first PV ice-maker developed by SunWize in the heart of the Chihuahuan desert for the fishermen of Chorreras.

The world's first automatic commercial PV ice-making system was installed in March 1999 to serve the inland fishing community. The Chorreras ice-maker system was designed and installed by SunWize Technologies of Kingston, New York, with the assistance of Energía Solar de Ciudad Juárez (ENSO) from Chihuahua. This project was possible due to the support of developing high-value renewable energy applications provided by the New York State Energy Research and Development Authority (NYSERDA), which had teamed with SNL, the State of Chihuahua, and the NMSU to develop, install, maintain, and monitor a PV hybrid ice-maker. The project was done in coordination and with cost-shared funding assistance from the USAID/DOE MREP.

The US $\$ 38,000$ hybrid system was operated from 1999 to 2002 and produced an average of $8.9 \mathrm{kWh} / \mathrm{d}$ at $240 \mathrm{~V}$ to the icemaker. The system Coefficient of Performance (COP) was 0.65 and a total of $97 \%$ of the energy was supplied by the PV array, while the backup propane generator supplied only 3\%. Production of ice varied each month due to changes in insolation and ambient temperatures and averaged about $75 \mathrm{~kg}$ of ice/d. About every 9 months, the icemaker water lines would need to be cleaned to remove calcium deposits. With a fixed timer setting, the icemaker operated daily for 3 hours with a dozen 15 minute cycles at night to make ice, except on Sundays (no fishing). 


\subsection{Ice-making system design}

The concept of solar-powered ice production in the remote desert is not a trivial one. High solar insolation certainly maximizes ice-making potential, but likewise high ambient air temperatures of over $40^{\circ} \mathrm{C}$ in summer also reduce that potential. The northern Chihuahuan desert has high summer ambient temperatures, as well as winter temperatures well below freezing, which is an abusive environment for batteries. These considerations led to some interesting design and operational challenges. Finding an acceptable freshwater source was another challenge since the fishermen wanted to be able to use the ice for personal use as well. This desire eventually resulted in the community building a $7 \mathrm{~km}$ gravity flow aqueduct across the rocky desert ground from a clean spring water source.

The PV hybrid system is built on a galvanized steel frame bolted on a concrete platform and consists of the following major components: $2.4 \mathrm{~kW} \mathrm{PV}$ array (fixed $30^{\circ}$ array tilt) with 32 Siemens SP75 solar modules, Ananda Power Technologies (APT) power center, 24 Vdc 2200 Ah battery bank with $2 \mathrm{~V}$ cells, two Trace Engineering $3.6 \mathrm{~kW}$ modified sinewave inverters provide 240 Vac electricity and one Kohler $6.3 \mathrm{~kW}$ propane fueled generator.

Figure 10 shows a one-line diagram of the complete PV hybrid ice-making system. The propane-fueled generator was included in the design to provide backup battery charging and boost ice production when needed for larger fish hauls and/or cloudy weather. Operation is controlled automatically through inverter set points. The batteries absorb high current transients and allow for load shifting to nightime for more efficient summertime ice production when cool ambient temperatures are favorable for maximum ice production. The battery bank is thermally insulated and uses dc fans for cooling and hydrogen venting. Two Trace modified sinewave inverters are stacked together to deliver $60 \mathrm{~Hz}, 240 \mathrm{Vac}$ single-phase power for the icemaker.
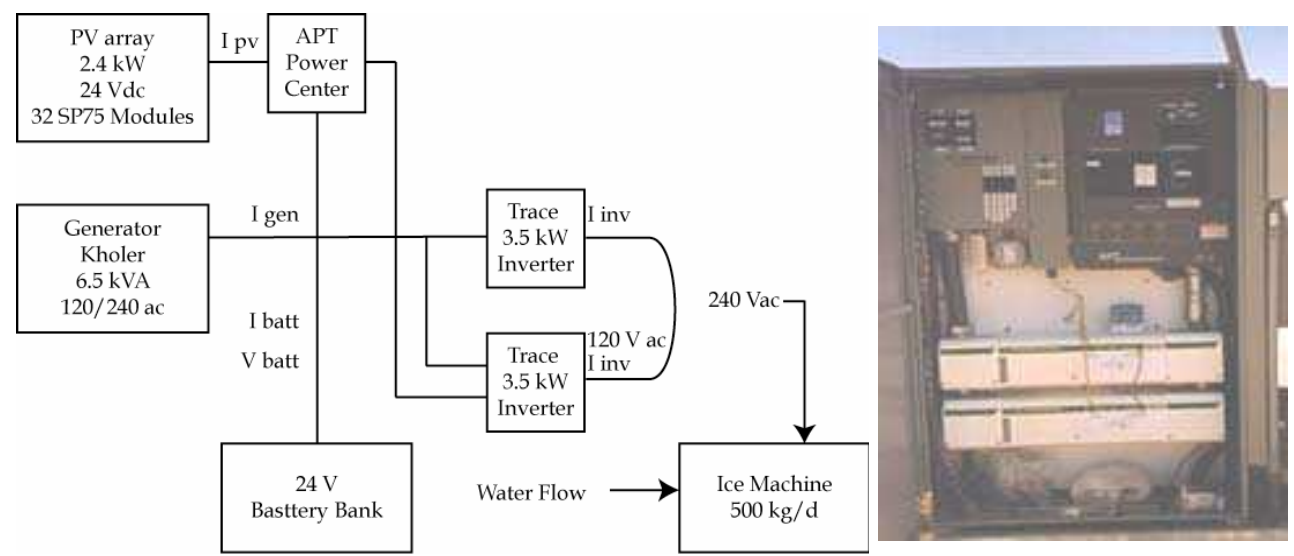

Fig. 10. Icemaker diagram and system Trace DR series inverters and APT power center with disconnects.

The icemaker is a vertical-evaporator compression-cycle unit installed on the roof of the fish storage building. It was designed for low maintenance and high reliability. For this specific application, modifications were made to the icemaker to reduce power consumption. A smaller compressor and condenser heater was modified resulting in a reduced current from approximately 22 to $11.5 \mathrm{Amp}$ at $240 \mathrm{Vac}$, thus reducing power requirements by about $40 \%$. A $7 \mathrm{~km}$ aqueduct was installed by the Chorreras community to the fish storage facility to 
provide high-quality water. The polypropylene pipeline was buried $0.3 \mathrm{~m}$ in the hard desert rock soil to help provide lower water supply temperatures. Approximately $1.5 \mathrm{~km}$ from the icemaker stands a $10 \mathrm{~m}^{3}$ storage tank on top of a hill that provides consistent gravity water flow with sufficient pressure for the icemaker (Hoffstatter, 2000).

The icemaker is set to run a dozen or so 15-min automatic ice-making cycles each day (about 3 hours a day). The system freezes the water, a crusher breaks the ice into convenient flakes, and the ice falls via gravity into a cold storage room. The PV system typically produces about $90 \mathrm{~kg}$ of flake ice per day. However, production of ice can be increased by manual operation of the generator allowing a maximum ice production capacity of more than 400 $\mathrm{kg} /$ day. The timer is set to provide no ice on Sundays (a day with minimal fishing) to allow the PV array to fully charge the battery bank and help equalize the batteries each week.

\subsection{System reliability}

A data acquisition system (DAS) was designed, built, and installed by NMSU for SNL and SunWize to monitor system performance. The DAS was installed in March, 1999 and uses a GOES-based satellite communication system for the remote site. The DAS consists of a Campbell Scientific CR-10X Datalogger, electronic transducers, and an assortment of other sensors. The DAS is used to measure several environmental and system parameters including: PV current, generator run-time, generator current, battery voltage, current and temperature, load voltage and current, ice-room and ambient temperatures, insolation at the array inclination and water flow. The stored data is hourly averaged and transmitted every four hours via the GOES satellite. Monthly data reports allow the project team to monitor system performance and identify any potential problems.

The icemaker is set to operate during the cool, late-night hours during the summer since the high ambient and water temperatures reduce the system ice-making efficiency during the daylight hours. The load is driven solely by the batteries at night while the PV array replaces the consumed energy during the day. This nighttime operation results in deep-battery discharge cycles but increases ice production. In the winter, the system is used to produce ice during the daylight hours, allowing the PV array to provide some energy, extending battery lifetime.

Adjustments to the compressor and modifications on the control timer improved the ice production from a daily average of $80 \mathrm{~kg}$ of ice during the first three months of operation to $90 \mathrm{~kg}$.

Daily, weekly, and seasonal weather differences results in variations in the generator run time. During the longer summer days, generator operation is more infrequent. During the first 14 months of operation, the generator provided only $3 \%$ of the total energy used.

The batteries are enclosed in a thick-walled, insulated industrial plastic enclosure filled with water and baking soda; however, temperatures in excess of $45^{\circ} \mathrm{C}$ (hourly average) were recorded while the batteries were being charged. The original passive cooling vents and a small hydrogen vent fan were not cooling the batteries sufficiently after installation; a dc cooling fan was added in July, 1999 to the battery container which remediated high battery temperatures and kept the battery bank below $40^{\circ} \mathrm{C}$.

\subsection{System performance}

Figure 11 summarizes the energy performance of the system from April 1999 - May 2000. The PV array supplied a total of 3,542 kWh (253 kWh monthly average) of energy; the 
generator delivered a total of $115 \mathrm{kWh}$ of energy. The total energy input to the system (PV plus generator) was $3,657 \mathrm{kWh}$ over the 14 months.

The ac load (ice-maker) consumed a total of 2,075 $\mathrm{kWh}$ allowing for an overall system efficiency (energy-out/energy-in) of $57.4 \%$. The battery performance for the first 14 months of operation was found to provide a $50 \%$ round-trip efficiency (discharging to charging ratio). Both inverters run continuously, while supplying power to the ac load and the DAS. The roundtrip battery bank efficiency (discharging to charging ratio) was steady throughout the first year indicating little to no change for overall battery bank capacity.

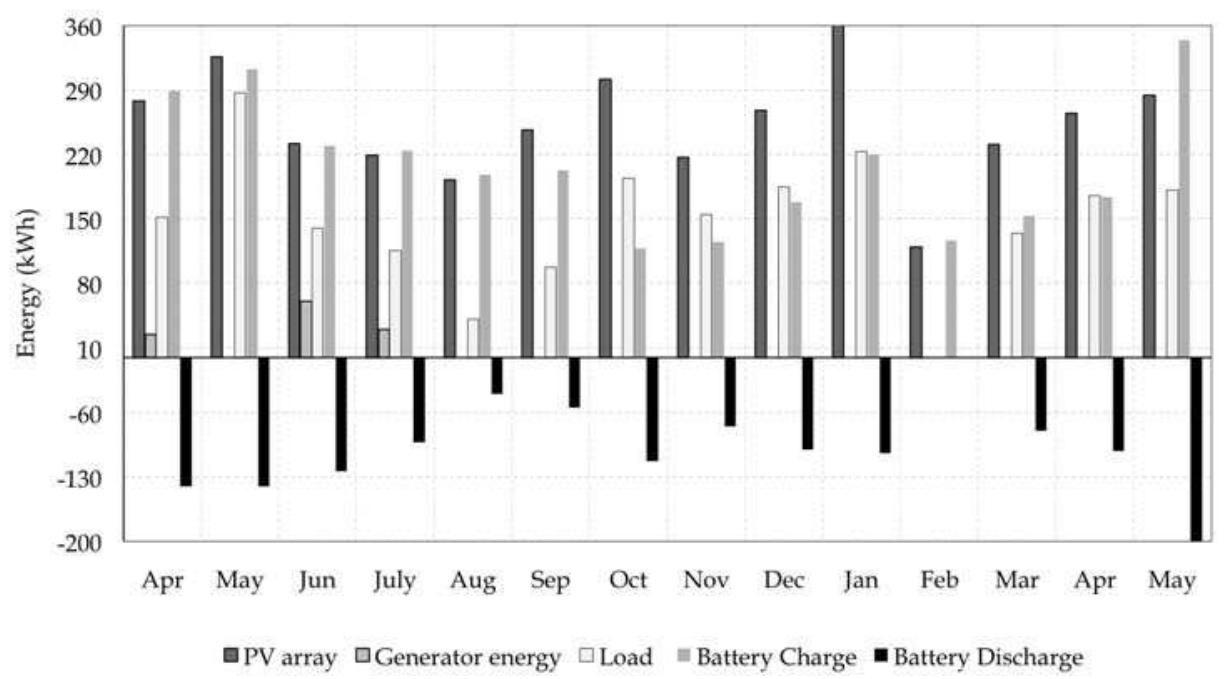

Fig. 11. First year system energy performance.

\subsection{Economics of the system}

The State Government of Chihuahua purchased the ice-making system for US\$38,000 with cost-share assistance from Sandia and USAID. In addition, the State of Chihuahua and the community of Chorreras pitched in additional funds to build the $7 \mathrm{~km}$ aqueduct and to rehabilitate the ice-room. NYSERDA funded engineering design and development for this novel system, and Sandia funded the DAS and follow-up system monitoring. Thus, the final cost for this project was about US $\$ 150,000$. However, the value of the now commercialized PV ice-maker unit is about US\$50,000.

Ice production has been found to be about $11.5 \mathrm{~kg}$ per sun hour with an overall COP of about 0.65 . The system can produce over $25,000 \mathrm{~kg}$ of ice per year from the solar alone. Assuming a value of US\$0.30 per $\mathrm{kg}$ of ice (for this remote site where it must be hauled in), this implies that a simple payback for the ice-making system is under 7 years. Taking into account the value of reduced fish spoilage, actual payback is actually well under 5 years for the PV icemaker. Overall, it is anticipated that ice production over the system lifetime, with future battery replacements and system maintenance, should be about US\$0.15 per $\mathrm{kg}$. Of course, having a reliable source of ice in the desert for a cold drink has an intrinsic value that is difficult to express simply in terms of dollars and cents. 
It is important to include thermal consideration in the design of battery racks or containers. Even small thermal differences among batteries can contribute to battery decay in the longrun. A strict maintenance schedule and procedure is required for batteries that pays special attention to safety. This schedule includes adding water and monitoring battery temperature and voltage. In periods of low insolation (winter with short days, or cloudy seasons) consideration might be given to adjusting the inverter set points to allow longer generator run times. Manually initiated frequent (monthly) equalization periods are also recommended.

For any type of relatively complicated hybrid system, it is important to not only consider the technical side of the equation, but the institutional side as well. The system has proven that a properly designed, operated, and maintained system can indeed produce a significant and valuable resource, such as ice, even in the middle of the desert. However, such a successful system requires local buy-in and follow-up, and a complicated system such as this if it was simply "parachuted in" would soon not be functioning due to relatively minor problems that require an experienced technician to solve. Long-term commitment and follow-up by the project partners is required for project success. This project is a good example of using renewable energy as a tool to contribute to local economic development in a remote area.

The icemaker performed adequately for the first three years of operation. The project showed that a properly designed, operated, and maintained PV system can indeed produce a significant and valuable resource, such as ice, even in the middle of the desert. Long-term commitment and follow-up by the Mexican project partners was necessary for continued project success. Unfortunately, there were State political changes and the area faced a severe drought. The lake receded over $2 \mathrm{~km}$ from the ice house by 2003 and the fisherman moved their catch out to the other end of the resevoir. The ice-making system was shut down and unfortunately has not been operated since. Other Mexican coastal communities attempted to purchase the unused ice-making system, but the Chorreras community refused to sell it in the belief they may one day again reactivate it.

\section{PV refrigerators}

A significant development for PV refrigeration technology came from SunDanzer in support of NASA. The SunDanzer refrigerator uses thermal storage, and a direct connection is made between the cooling system and the PV panel. This is accomplished by integrating a waterglycol mixture as a phase-change material into a well-insulated refrigerator cabinet and by developing a microprocessor-based control system that allows direct connection of a PV panel to a variable-speed dc compressor. The refrigerator uses a more efficient variablespeed dc compressor. The unit is designed to run on 90 to 150 watts of PV power (needed for compressor start-up), but only draws about $55 \mathrm{~W}$ when cycling. During cloudy weather, internal thermal storage keeps products cold for a week, even in a tropical climates. The battery-free unit is designed to work optimally in locations with at least 4 sun-hours per day using a variable speed compressor and peak power tracking.

NMSU began testing solar refrigerators in July 2000 at its facilities and later in the field in 2002. Units were field tested on the Navajo Indian Reservation in New Mexico; in Chihuahua and Quintana Roo in Mexico; and at the highlands of Guatemala through Fundación Solar. The unit offers the most economical method for on-site refrigeration for rural people. Based on these results and lessons learned, only in 2010, did SunDanzer finally launch a commercial battery free solar refrigeration unit that can be purchased today. 


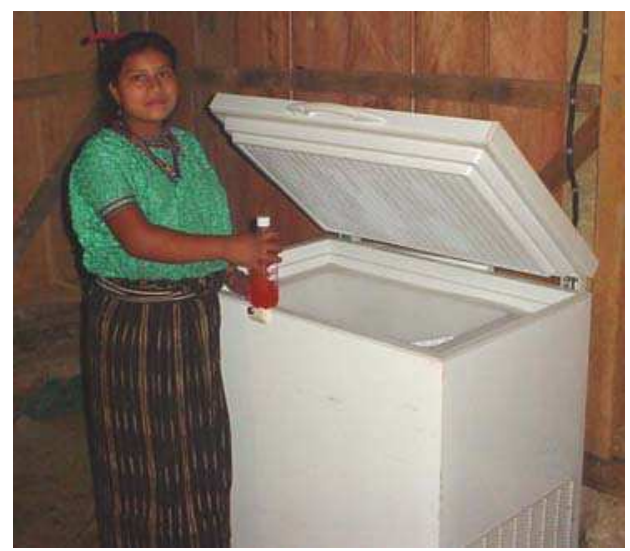

Fig. 12. SunDanzer PV direct drive refrigerator piloted in the indigenous Mayan village of Santa Clara, Quiché, Guatemala by NMSU, NASA, and Fundación Solar in 2002.

\section{PV for schools}

Thousands of rural schools in Latin America do not have grid power. Solar power offers a practical way to meet their power needs. Many early school PV systems often failed and gave the technology a poor image. Around 2000, PV school installations in many parts of Latin America began to show great improvements as the industry matured. Large-scale rural school electrification programs have been implemented in Mexico, Guatemala, Cuba, Honduras, Peru, and Brazil. For instance, the Fundación Solar and the Fundación para el Desarrollo Rural de Guatemala began using PV to bring distance education programs to remote areas that were devastated by Hurricane Mitch in 2000. The PV system is used to power televisions, videocassette recorders, and computers to modernize the educational

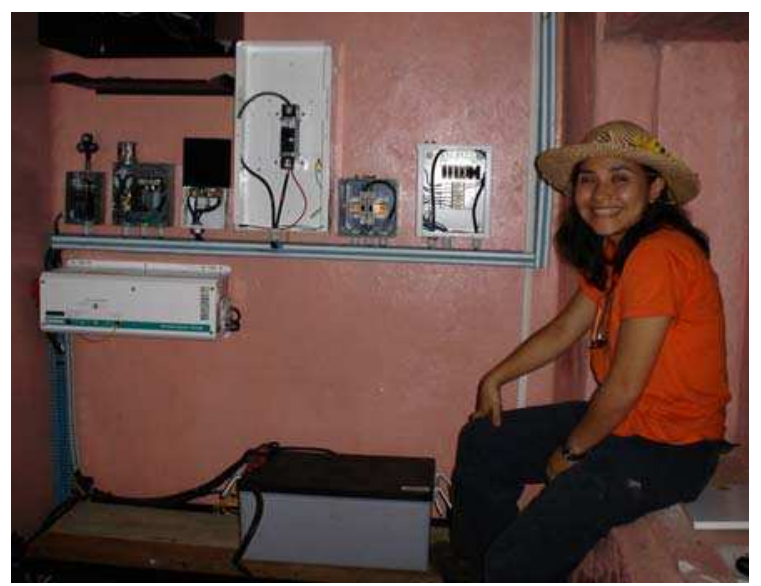

Fig. 13. COHCIT Sosoal PV satellite telecenter with internet connectivity using quality BOS components with SOLARIS installer Ethel Enamorado in Lempira, Honduras. 
experience of rural school children. Mexico has over 500 PV powered schools, with some of the best examples being the $54 \mathrm{PV}$ telesecundaria schools in Chihuahua installed in November, 2002 by EDUSAT/State of Chihuahua for satellite education. MREP provided technical advice to avoid common errors.

The Consejo Hondureño de Ciencia y Tecnología (COHCIT) has installed a half dozen quality PV telecenters/schools in rural Honduras with assistance from NMSU. COHCIT with the World Bank set up a first pilot PV powered telecenter in the community of Montaña Grande near Tegucigalpa in 2003. As a result of this, COHCIT installed 5 more telecenters in 2004 with the Inter-American Development Bank and is planning more.

\section{PV for protected areas}

Renewable energy technologies have been widely applied to support protected area throughout Latin America, especially in Guatemala and Ecuador (Galapagos) (Ley \& Stoltenberg, 2002). Mexico with MREP has installed over 70 solar systems in protected areas such as Isla Contoy, El Eden, Montes Azules, and Sian Ka'an Reserves with the Mexican Secretariat of Environment and Natural Resources (SEMARNAT), the Nature Conservancy, World Wildlife Fund, and Conservation International.

Use of solar in protected areas benefits the living conditions of researchers, technicians, and rangers, as well as providing energy for environmental training centers. The solar systems also have the advantage of providing power without the noise or pollution associated with conventional fossil-fueled generators, while reducing the risk of fuel spills in these sensitive biosphere reserves. As always, up front design decisions, user operation, and long-term maintenance issues play an important role for overall system reliability.

Solar energy is an environmentally appropriate example to neighboring buffer communities (often without electricity) surrounding biosphere reserves which can likewise benefit by replicating the protected areas example. Solar systems also provide a useful example for visitors and tourists to take back home.

In addition, the remote protected area facilities benefit economically from solar installations through reduced operation and maintenance costs associated with fossil fuel generators. Actual system life-cycle costs for any particular solar or wind energy system varies and is a function of design, usage, application, and maintenance. With proper system operation and maintenance, the expected solar system lifetimes should exceed 25 or more years (with appropriate battery replacements, etc.).

\section{Hybrid systems}

The road for hybrid system application in Latin America has been difficult. While the various solar technologies are proven, the institutional and organizational issues for these more complicated systems have proved to be the most difficult to overcome. Some of the key hybrid projects implemented in Latin America include the Campinhas project in Brazil, and the Xcalak and San Juanico systems in Mexico.

In 1992, the State Government of Quintana Roo funded the installation of the world's largest (at that time) wind/solar village hybrid system in Xcalak. The idea was to provide additional hours of power for the community beyond the 3-4 hours per day that the diesel 
was operated. The combined wind/PV hybrid system hardware cost was approximately US $\$ 450,000$ and installed by Condumex. The generation system consisted of six Bergey Windpower nominally rated $10 \mathrm{~kW}$ Excel wind turbines and $11.2 \mathrm{~kW}$ of Siemens PV modules. Energy was stored in two battery strings using 216 GNB Resource Commander batteries for a combined total of $1738 \mathrm{Ah}$ at $220 \mathrm{~V}$. The stored energy was provided to the town's electric grid via an Advanced Energy Systems $40 \mathrm{~kW}$ sinewave inverter.

Originally the wind and PV system output was adequate to nearly meet the entire village's electric power demand for 24-h power. However, the village loads rapidly grew after system installation (53\% in the first year alone) and there were no electric meters. By 1997 the Xcalak renewables system provided less than $30 \%$ of total community power due to significantly increased loads and lack of system maintenance.

After five years, the system ceased to function altogether, in particular due to the failure of the $40 \mathrm{~kW}$ inverter, which faced a difficult job in Xcalak with highly unbalanced system loads and corrosion exacerbated by drawing humid air from below ground concrete raceways.

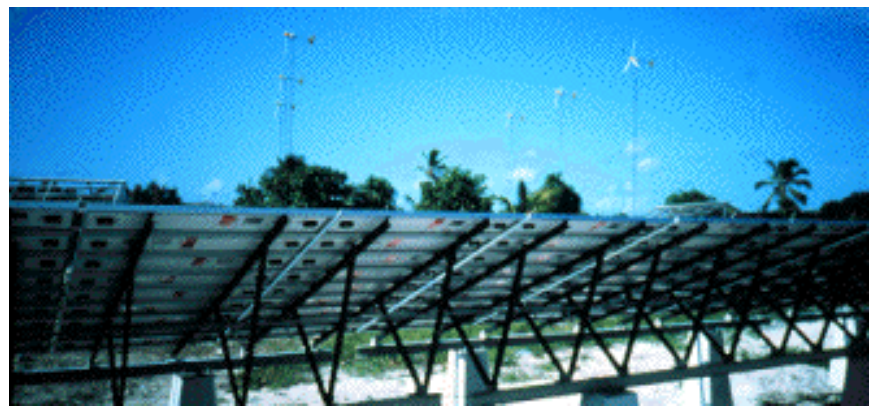

Fig. 14. Xcalak, Mexico wind turbines and PV array (1993).

The early years of the Xcalak hybrid system showed that wind and PV technologies can provide abundant and reliable electric service. However, the lack of institutional planning led to inadequate system maintenance, excessive load growth, and eventual system failure. For hybrid systems to be a viable, an adequate and manageable institutional structure must accompany the technology. To avoid failure, village hybrid systems must include realistic system sizing and proper institutional controls from the onset.

\section{Lessons learned}

When developing solar projects in Latin America, there is a tendency for some organizations to focus on the technology, while other focus largely on institutional issues. The happy medium takes into account both and promotes partnerships, local capacity building, quality technical design, and monitoring and evaluation.

Some key considerations for any solar project include: Develop solid partnerships, conduct strategic planning, use grass-roots development approach, foster reasonable end-user expectations, create sustainable markets, promote capacity building, size appropriately, obtain user input, develop a professional design, insist on quality, conduct preventive and regular maintenance, anticipate future growth, maintain parts supply inventory, consider 
safety and security, demand guarantees and warranties, conduct follow-up and evaluate results and think sustainability.

When developing solar projects in Latin America, there is a tendency for some organizations to focus on the technology, while other focus largely on institutional issues. The happy medium takes into account both and promotes partnerships, local capacity building, quality technical design, and monitoring and evaluation. Some key considerations for any solar project include the following:

- Develop solid partnerships: The most sustainable and viable projects are formed when in-country agencies partner with industry. It is important to choose partners carefully.

- Conduct strategic planning: Strategic planning with collaborating partners helps to create realistic goals that makes PV as a useful tool for established programs. Planning should include sufficient promotional activities to accelerate acceptance, including training.

- Use grass-roots development approach: An integrated and grass-roots development approach across a critical mass of different agency types provides a strong base for dissemination and replication. A local and capable champion greatly facilitates local solar development.

- Foster reasonable end-user expectations: Do not oversell PV technologies and capabilities that might disappoint users. End-users want quality systems that work and supplies them the power they need.

- Create sustainable markets: Financing is a major barrier to market growth. Renewables must be cost accessible to rural people and often require smart cost-sharing or financing. Reinforce commitment to sustainability and perceived system value from systems that are donated to ones that users find affordable through micro-credit lending.

- Promote capacity building: In-depth training is critical. It is important not only to train project developers, but also users and local industry (supply side). Success depends largely on the technical capacity of local technicians, users, and administrators while considering gender issues. Adopt participatory techniques in community projects.

- Size appropriately: System sizing and design needs to be focused and realistic as to user needs and loads to avoid unnecessary expenditures on larger systems than required. The system needs to meet the loads now and be expandable for the future. Choose energy saving devices to reduce PV system size and save money.

- Obtain user input: Clearly identify user needs and develop appropriate technical specifications for a system to meet those needs. Consider technical, gender, and cultural issues as well as economic constraints.

- Develop a professional design: Design parameters should be developed by experienced engineers and include realistic system usage, climatic conditions, component selection, O\&M considerations, safety, and reliability considerations.

- Insist on quality: Installations should be made by experienced technicians that exhibit good workmanship and meet electrical code requirements. For larger programs, acceptance testing of installed systems should be conducted to verify that contractual obligations have been met.

- Conduct preventive and regular maintenance: O\&M is required for long-term successful system operation. There are diverse maintenance levels. Some actions can be undertaken by the end-user, while more complex tasks requiring a skilled technician. Proper tools must be provided. An O\&M actions journal is recommended. 
- Anticipate future growth: Design a system accordingly for relatively seamless expansion.

- Maintain parts supply inventory: Required for components that are likely to be replaced (e.g., fuses). Build a strong supplier network. Try to use appropriate local components as much as possible to avoid delays in replacement parts. Facilitate links between the end-users (men and women) and equipment suppliers.

- Consider safety and security: Design with safety in mind, meet all applicable codes and standards. Be vigilant as to potential theft, vandalism, etc., and plan accordingly.

- Demand guarantees and warranties: Use reputable vendors who offer guarantees and know what these are. Consider long-term preventive maintenance contracts for system support with the equipment vendor.

- Conduct follow-up and evaluate results: Monitoring and follow-up are key to understanding the true results for any program. End-user surveys can provide valuable feedback in regard to customer expectations, usage patterns, and overall satisfaction. This information helps with future planning.

- Think sustainability: All paths should lead to this and institutions applying solar systems must have a true commitment for long term sustainability. Government agencies face particularly difficult challenges with often changing parties in power. The ultimate goal is to have a well designed and installed solar system that will provide many years of reliable and satisfactory service. The past twenty years have set the stage for future solar development in Latin America, which is growing exponentially.

\section{References}

Cota, A. (2004a). Azteca Solar: The Mexico Renewable Energy Program. US Department of Energy, Sandia National Laboratories y Southwest Technology Development Institute. New Mexico State University- SWTDI on line. (http:// solar.nmsu.edu/publications/index.htm\#mex).

Cota, A.; Foster, R.; Gómez, L.M.; Ross, M.P.; Hanley, C.H.; Gupta, V.P.; Montufar, O \& Paredes, A.R. (2004). Ten year reliability assessment of photovoltaic water pumping in México. Proceedings of the American Solar Energy Society: SOLAR 2004, Portland, Oregon, USA.

Foster, R.; Ghassemi, M. \& Cota, A. (2009). Solar Energy: Renewable Energy and the Environment. In the Series: Energy and the environment. Series Editor de series: Ghassemi, A. First Ed. CRC Press. ISBN: 352 978-1-4200-7566-3, Boca Raton, FL, USA.

Foster, R.; Ley, D.; Martinez, H.; Estrada, L. \& Lara, E. (2006). Nicaraguan renewable energy for rural zones program initiative. Proceeding from Solar 2006 of the American Solar Energy Society, ASME International Solar Energy Conference - Solar Engineering, Denver, CO, USA.

Foster, R.; Cota, A. \& Estrada. L. (2004). Five-year reliability assessment for SoListo photovoltaic home lighting system in Chihuahua. Proceedings of American Solar Energy Association Annual Conference. Portland, Oregon.

Foster, R. E.; Estrada, L.; Gomez, M. \& Cota, A. (2004). Evaluación de la confiabilidad de los sistemas FV SOLISTO en Chihuahua, Proceedings of the $12^{\text {th }}$ Intnl. Symposium on Solar 
Power and Chemical Energy Systems, SolarPACES, 28th Semana de Energía Solar - ANES, Oaxaca, Mexico.

Foster, R.; Estrada, L.; Ojinaga-Santana, L.; Colmenero, J.; \& Ross, M. (2003). Utilizing photovoltaics to support distance education in the state of Chihuahua, Mexico. American Solar Energy Society, Austin, Texas.

Foster, R.E.; Estrada, L.; Stoll, S.; Ross, M. \& Hanley, C. (2001). Performance and reliability of a PV hybrid icemaking system, Proceeding of the 2001 Solar World Congress. International Solar Energy Society, Adelaide, Australia.

Foster, R.E.; Orozco, R. C.\& Romero, A. (1999). Lessons Learned from the Xcalak Village Hybrid System: A Seven Year Retrospective, Proceedings of the 1999 Solar World Congress. International Solar Energy Society, Vol. I, Israel Ministry of Science, Jerusalem, Israel.

Foster R. E.; Ghosh, S.; Carrillo, O.; Molina, D. \& Panico, D. (1998a). Willingness to pay for solar photovoltaic energy lighting systems: The case of rural Chihuahua," Proceedings of the 1998 Annual Conference, American Solar Energy Society, 21-25, Albuquerque, NM.

Foster, R. E.; Cisneros, G. \& Hanley, C. J. (1998b). Life-cycle cost analysis for photovoltaic water pumping systems in Mexico, Proceedings of the 2nd World Conference on Photovoltaic Energy Conversion, 15th European PV Solar Energy Conference, 27th US IEEE Photovoltaics Specialists Conference, 10th Asia/Pacific PV Science and Engineering Conference, Vol. III, ISBN 92-828-5420, 3021-3025,Vienna, Austria.

Hanley, C.; Ross, M.; Montufar, o.; Rovero, C.; Foster, R.E. \& Ellis, A. (2001). Introducing photovoltaics to new markets through government development programs: The FIRCO Example in Mexico, Photovoltaic Systems Symposium, Sandia National Labs, US Department of Energy, Albuquerque, New Mexico, July 20, 2001.

Hoffstatter, L. \& Meraz, V. (2000). One-year maintenance report, Sunwize Technologies \& Energía Solar de Ciudad Juárez, October 1999, March 2000.

Hoffstatter, L. and Schiff, M. (2000). Commercial solar electric ice plant - A first year report," Proceedings of the American Solar Energy Society, ASES 2000 Annual Conference, Madison, Wisconsin.

Ley D.; Hanley, C.; Foster R. \& Mazariegos G. (2006). Rural Honduran PV powered schools and community centers. Proceeding from Solar 2006 of the American Solar Energy Society, ASME International Solar Energy Conference - Solar Engineering, Denver, CO, USA.

Ley, D. \& Stoltenberg, B. (2002). Hybrid electric systems for the Galapagos. Proceedings from the $26^{a}$ Semana Nacional de Energía Solar of the Asociación Nacional de Energía Solar, Chetumal, Quintana Roo, México.

Ojinaga, L.M.; Rovero, C.; Foster, R. E. \& Trespalacios, A. (2000). Programa de financiamiento para energía renovable en Chihuahua, Mexico. Proceedings of the Millennium Solar Forum 2000, International Solar Energy Society, Asociación Nacional de Energía Solar, 737-740. Mexico City, Mexico.

Richards, E.H.; Hanley, C.; Foster, R.E.; Cisneros, G.; Rovero, C.J.; Büttner, L.; Ojinaga Santana, L.; Graham, S.; Estrada Gasca, C. A. \& Montufar, O. (1999). Photovoltaics in Mexico: A model for increasing the use of renewable energy systems, Advances in Solar Energy: An Annual Review of Research and Development, Vol. 13, Energy, American Solar Energy Association, Boulder, Colorado. 
Romero-Paredes, A.; Foster, R. E.; Hanley, C. \& Ross, M. (2003). Renewable energy for protected areas of the Yucatán Península, Proceedings of the American Solar Energy Society, SOLAR 2003, Austin, Texas.

SWTDI (2000). Chorreras system monthly performance summaries, for Sandia National Laboratories, Las Cruces, New Mexico, April 1999 through May 2000.

Wiles, J. (1996). Photovoltaic power systems and the National Electrical Code: Suggested practices (Sistemas de energía fotovoltaica y el Código Eléctrico Nacional: Prácticas recomendadas), Southwest Technology Development Institute, New Mexico State University, Las Cruces, NM USA. Supersedes SAND96-2797. 


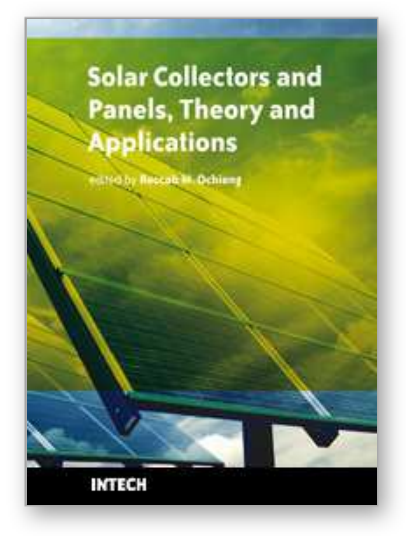

\author{
Solar Collectors and Panels, Theory and Applications \\ Edited by Dr. Reccab Manyala
}

ISBN 978-953-307-142-8

Hard cover, 444 pages

Publisher Sciyo

Published online 05, October, 2010

Published in print edition October, 2010

This book provides a quick read for experts, researchers as well as novices in the field of solar collectors and panels research, technology, applications, theory and trends in research. It covers the use of solar panels applications in detail, ranging from lighting to use in solar vehicles.

\title{
How to reference
}

In order to correctly reference this scholarly work, feel free to copy and paste the following:

Alma Cota and Robert Foster (2010). Photovoltaics for Rural Development in Latin America: A Quarter Century of Lessons Learned, Solar Collectors and Panels, Theory and Applications, Dr. Reccab Manyala (Ed.), ISBN: 978-953-307-142-8, InTech, Available from: http://www.intechopen.com/books/solar-collectors-andpanels--theory-and-applications/photovoltaics-for-rural-development-in-latin-america-a-quarter-century-oflessons-learned-

\section{INTECH}

open science | open minds

\author{
InTech Europe \\ University Campus STeP Ri \\ Slavka Krautzeka 83/A \\ 51000 Rijeka, Croatia \\ Phone: +385 (51) 770447 \\ Fax: +385 (51) 686166 \\ www.intechopen.com
}

\author{
InTech China \\ Unit 405, Office Block, Hotel Equatorial Shanghai \\ No.65, Yan An Road (West), Shanghai, 200040, China \\ 中国上海市延安西路 65 号上海国际贵都大饭店办公楼 405 单元 \\ Phone: +86-21-62489820 \\ Fax: +86-21-62489821
}


(C) 2010 The Author(s). Licensee IntechOpen. This chapter is distributed under the terms of the Creative Commons Attribution-NonCommercialShareAlike-3.0 License, which permits use, distribution and reproduction for non-commercial purposes, provided the original is properly cited and derivative works building on this content are distributed under the same license. 